\title{
Developing a Graded Examination for the Malay Gamelan
}

\author{
Shahanum Mohamad Shah \\ Department of Music Education. Faculty of Music, Universiti Teknologi MARA, \\ 40200 Shah Alam, Selangor, Malaysia \\ e-mail: shahanum@salam.uitm.edu.my \\ Zaharul Lailiddin Saidon \\ Faculty of Music and Performing Arts, Sultan Idris Education University, \\ 35900 Tanjong Malim, Perak Darul Ridzuan, Malaysia \\ e-mail: zaharul@fmsp.upsi.edu.my
}

Published online: 16 June 2017

\begin{abstract}
The traditional music of Malaysia appears to be sidelined in favour of music which is more accessible and readily available to the younger generation. The lack of exposure to traditional music breeds unfamiliarity of this music and hence is not appreciated or understood by most Malaysians. As music is an integral part of human culture, it is important for this genre of music to be sustained for the future generation. As compared to the availability of examination systems for Western music, there are no mechanisms for assessing musical attainment for the local music traditions in Malaysia. A structured system for assessing and awarding certificates based on levels of achievement in the local music traditions is needed which will provide a platform for musicians involved in the local music traditions to benchmark their achievements and obtain the necessary qualifications which can assist them in furthering their studies or gain employment. This paper discusses the development of a graded examination system for the Malay gamelan in an effort to sustain this tradition. This study used the qualitative method whereby both desk work and field work are conducted. Research methods used include observation of performances, being a participant-observer during practices, interview sessions and focus groups with various practitioners from Malaysia and Indonesia and audio/visual documentation. Guidelines on developing a graded examination system for the Malay gamelan are discussed.
\end{abstract}

Keywords: assessment, graded examination system, Malay gamelan, music examinations, traditional music

\section{Introduction}

Music examinations have existed for a long while with the purpose of recognising achievements and standards of performance. In graded examinations of musical 
performance, the demonstration of progressive levels of mastery differentiates the novice and the more accomplished musician. These levels are used to define increasing mastery in skills, techniques and knowledge required of a musician. These examinations require a live performance by the candidates. Within an examination, differentiation is by both content and outcome. Content is determined by repertoire selected to represent an appropriate level of difficulty for the grade to be examined while outcome is determined by the demonstration of performance expectations that match or exceed the minimum levels of mastery required (Robbins, 2007, p.5).

As opposed to the numerous music examination boards found for Western classical and popular music traditions, music examination boards for traditional music genres are fewer in comparison. A review of literature indicates that examination systems have been developed for traditional or non-Western music instruments and music genres specifically in the Indian, Chinese, Scottish and Irish music traditions. Among these are the Carnatic Examination System and the Taali Foundation Music Examination System for Indian music and the Irish and Scottish Traditional Music Exam. These exams are similar to the examination systems for Western music instruments in that they are graded and require playing selected repertoire for the particular instrument opted by the candidates.

As society becomes more sophisticated in this new millennium of technology and globalisation, Malaysia is facing greater and different challenges from those of the previous century (Razak, 2002; Yeoh, 1999). One such challenge is to preserve the nation's cultural heritage and identity. While the government aims to prepare its people for global competition and focuses on science and technology, there is a strong tendency for the arts and culture to be continually sidelined. Almost three decades ago, Mohamed Ghouse Nasuruddin (1979) warned that Malaysians were becoming strangers to their own cultural heritage and were ignorant about local traditional and folk music to the extent that "they regard these arts as misfits in the contemporary world of disco dance and soul and rock music. This attitude is particularly noticeable in the urban areas where the Western style of life is the norm". Nettl (1985) also pointed out that the speed with which Western music was added to the indigenous repertory — or replaced it — was indeed amazing. Studies by Shahanum (2000) and Yeoh (1999) show that teenage Malaysian students today not only prefer popular Western music but are unfamiliar with Malaysian ethnic music.

Nettl (1985) stated that "the most significant phenomenon in the global history of music has been the intensive imposition of Western music and musical thought upon the rest of the world" (p. 3). In the case of Malaysia, the impact is great due to the long acculturation process that had occurred during more than 100 years of British rule in the country. It is not surprising that the music education practice in Malaysia is organised to a large extent around the great tradition of Western classical music. This can be observed at all levels of institutionalised music learning, from the design of the curriculum right to the teaching approaches used in the classrooms. Of this is the dependency on predominantly foreign music examination boards such as the Associated Board of the Royal Schools of Music (ABRSM) and the Trinity College London International Music Exam Board. 
As the foreign examination boards are mainly for Western art and popular music and therefore lack the traditional music element, they do not help to inculcate appreciation towards local music traditions. Currently, there is no mechanism for assessing musical attainment for the local music traditions of Malaysia. As such, there is an overemphasis on Western art and popular music at the expense of promoting local music. A structured system of assessing and awarding certification based on levels of achievement in local music traditions is needed to provide a platform for musicians involved in the local music traditions to benchmark their achievement and obtain the necessary qualifications which can assist them in furthering their studies or gain employment. As with examination systems that cater for non-Western musical instruments, there is a need for a specific examination system for Malaysian local music traditions. In addition, the current standard grading of professional musicians can be used by the government and the music industry as a benchmark of musical attainment since examinations of performance are a form of qualifying examination for a professional association (Robbins, 2007). This will also address the sustainability of local music traditions and the musicians.

The purpose of this study is to propose a graded examination system for the Malay gamelan in an effort to sustain the tradition.

\section{Literature Review}

Music examinations are typical in school and university music programmes. However, there are also independent bodies that offer music examinations that are open to all. Having its beginnings in England in Western classical music more than 150 years ago, examinations in popular music and jazz are also now being offered. These days, there are numerous music examinations for Western classical and popular music traditions with countries such as Australia and Japan establishing their own examination systems. These examinations require a live performance to be given ${ }_{2}$ in which one or more examiners assess the performance. Depending on the examination system being taken; such as the Yamaha Music Examinations, the examination may include supplementary tests of knowledge and understanding or aspects such as improvisation and transposition. Theory examinations are also offered but are separated to the performance examinations.

The practice of sending children for ABRSM piano and music theory lessons in Malaysia became a trend and had a social and symbolic significance amongst parents in the Malaysian urban society (Ross, 2002). ABRSM (2015) rightly claimed that most of the formal music education which young people receive in Malaysia is through private music schools or through a private teacher. Such is the widespread interest in Western music that many private music schools have become highly successful business enterprises operating from a chain of branches.

Leung (2003) pointed out that in many Asian countries, the Western classical music traditions challenges the existence of local traditional music. To much extent, the hegemony of Western classical music traditions accounts for the slow progress and the lack of success in the efforts of incorporating the various local music traditions in Malaysian schools, and to a certain extent, its sustainability. This 
situation is indeed alarming and, if allowed to persist, may jeopardise the future survival of Malaysian music traditions. Music is an important part of a nation's identity (Wan, 2008) and as such, emphasis should be given on developing local music traditions. Diverse musical practices in Malaysia exist but without a structured of training and assessment, which is academically accepted.

Mohamed Ghouse Nasuruddin (1979) indicated that there is a pressing needed for action on the part of "the government and institutes of higher learning to counteract the various forces which can be detrimental to the existence and progress of the traditional performing arts" (p. 464). Many have voiced the need to establish an accredited national body with the purpose of localising the exam curriculum and materials as well as providing assessments of music students' achievements (Ross, 2002; Choo, 2003; Mohd. Fadzil \& Thia, 2005).

The above discussion shows that formal education is a significant channel to create better appreciation and to promote traditional music amongst the younger generation. In other words, one of the key to the successful efforts of preserving the Malay music traditions is through a more structured curriculum, instruction and assessment in formal settings. While this may sound simple and straightforward, in reality it is an uphill and complex task to be implemented. This is because traditional music encompasses a different philosophy and practice from the Western music paradigm (Zaharul Lailiddin Saidon \& Shahanum Mohd Shah, 2015; Shahanum Mohd Shah \& Zaharul Lailiddin Saidon, 2016).

\section{Non-Western Music Examinations}

As mentioned above, there are not many music examination boards for traditional music genres. A review of literature indicates that examination systems have mainly been developed for traditional or non-Western music instruments and music genres specifically in the Indian, Chinese, Scottish and Irish music traditions.

The London College of Music started to offer Graded Awards in Chinese music that are performed in Chinese and assessed by examiners from the Chinese music community (Robbins, 2007). In order to provide awards for Chinese instrumentalists and singers, and to allow both amateur and professional musicians to gain recognition of a recognised international standard, proposals to adapt traditional graded examinations in Western music to Chinese music was mooted in the early part of 2006. These new awards allowed a wide range of repertoire with assessments in Chinese by Chinese musicians trained as assessors. A framework of eight graded awards and progressions to the diplomas was subsequently offered by the London College of Music (Robbins, 2007).

The Royal Conservatoire of Scotland offers the Scottish Traditional Music Graded Exams in instruments such as the fiddle (violin, viola or cello), accordion (button or piano key) and Scottish harp or clarsach. According to the examination manual, the assessment objectives are to provide clear milestones needed to build skills, knowledge and aural awareness required to perform Scottish music with authenticity and idiomatic dexterity. The exams are divided into four sections which are the performance of three pieces with fluency and continuity, a sense of style and 
musical character; technical work (scales, arpeggios and technical exercises), quick study (playing back a short piece of music by ear or by sight) and practical and aural musicianship (comprising a short series of tests to encourage understanding of traditional rhythms and tune idioms and visual communication between master and pupil or between musicians in a session). Candidates are assessed by examiners who themselves are experienced performers in the instrument concerned.

The London College of Music (LCM) Examinations offered by the University of West London also include examinations in Irish and Scottish traditional music in the subjects of solo instrumental and ensemble. Only Irish and Scottish music are accepted and all performances must be from memory. The Irish traditional music examination is offered for any one of the following instruments: fiddle, button accordion, piano accordion, melodeon, concertina, piano, guitar, uilleann pipes, harp, banjo, mandolin, whistle and flute. The Scottish Traditional Music examinations are offered in fiddle, cello, double bass, button accordion, piano accordion, melodeon, concertina, electronic keyboard, piano, Lowland and Highland pipes, harp, whistle, flute, guitar and voice. The examinations accept all regional styles, which are regarded as equally valid.

The National University of Singapore Centre for the Arts offers instrumental courses and examinations in Chinese traditional music with the first examination held in 2004. Among the objectives of the examination are to set up an examination system that will be recognised and accepted by institutions in Singapore and abroad and to establish a set of guidelines for facilitating systematic training in Chinese musical instruments. Examinations are offered in 16 instruments among which are the erhu, dizi, guzheng, pipa, yangqin, ruan, liuqin, sheng, zhongyin sheng, suona, zhongyin suona, hulusi and guan. For the Basic level (Grade 1-3) and the Intermediate level (Grade 4-6), candidates are required to perform one set of study piece incorporating scales and two solo music pieces. For the Advanced level (Grade 7-8), candidates are required to perform one set of study pieces incorporating scales, sight-reading and two solo pieces in addition to an aural test. Candidates for the Diploma examination need to perform three music pieces and is graded by two examiners.

The Central Conservatory of Music of China, China's most senior musical institute, also offers the Overseas Technique Grade Examinations in Chinese musical instruments such as the erhu, pipa, yangqin, guzheng, zhongruan, suona and dizi. Materials emphasise core technique as the principal of assessment and materials are organised in increasing levels of difficulty. Performance levels for all instruments are classified from level one to nine with the highest ranking being the Performance Certificate. The examinations consist of technique and oral sections. In the technique section, candidates of Grades 1-6 are required to play one etude and one music piece, while for Grades 7-10 and Performance Certificate, candidates need to play one etude and two music pieces of the corresponding examination level respectively. In the oral section, candidates of Grades 1-6 are asked about the selected music and extracurricular questions of sight singing and rhythm, while the oral test for candidates of Grades 7-10 is replaced with evaluation of general performance, music expression and technique. The examinations are also conducted in Chinese Mandarin. 
Several music examinations in Indian music exist. The Institute of Performing Arts and Heritage offers graded examinations in all subjects of Indian classical music such as the tabla, kathak, sitar, Hindustani vocal, Carnatic vocal, harmonium, flute and dhoi under the World Music and Dance Examinations category. The examination for the tabla, as an example, is divided into four levels; Level 1 consists of Grades 1, 2 and 3, Level 2 consists of Grades 4 and 5, Level 3 consists of Grades 6, 7 and 8 and Level 4 consists of Grade 9. Grades 1 and 2 are divided into the practical with viva component, Grades $3-9$ are divided into the practical and theory component but with weightage of marks being different according to the grade. For the viva component of Grades 1 and 2, candidates are asked questions pertaining to the understanding of terms, parts of the instrument or to give the life sketch of a tabla player from a given list. In Grades $3-9$, the theory component is in the form of a written test containing multiple choice, true or false, diagram, notation etc., on topics covered in the practical and theory syllabuses.

Examinations in Indian traditional music are also offered by the Academy of South Indian Music Board (London). A diverse range of exams and assessments are offered for voice and instruments and miruthanga (mridangam, tabla, ghatam and kanjira), from the Prep Test and Music awards for the earliest stages of learning through to professional diplomas at the highest levels of musical achievement. The examinations are also offered according to a graded system, from grade 1 to grade 8 and are divided into both theory and practical components.

While the aforementioned examinations exist for individual instruments within a solo and ensemble context, there are no such recorded examinations for traditional music which focus on ensembles whereby the candidate is required to be able to perform all the instruments within the ensemble. This would lead to different implications with regards to many aspects of the examination, such as the syllabus and the assessment mechanism. Therein lies the difference in the examination system for the Malay gamelan which requires the candidate to play all the instruments within the ensemble.

\section{Assessments of Music Performance}

According to McPherson \& Thompson (1998), music performance assessment is "the process by which one individual attempts to balance and synthesise the various qualities of a performance by another individual, with the aim of providing a judgement" (p. 12). The selection of evaluative criteria and evaluative instruments strongly shapes the evaluation process. The evaluation process may be defined as the implicit and explicit decisions that lead to an assessment. This process depends on a number of factors, including the training of evaluators, constraints placed on the evaluators, the physical environment and evaluator expectations (p. 19).

In any form of examinations, assessment criteria are important as it provides guidance to examiners and students on the type and level of performance required. Criteria for assessment of performances, although from different examination boards, typically tend to include similar aspects. As an example, the NCEA (2006) assessment criteria for performance states the importance of the candidate and the 
assessor knowing the context and conditions for assessment. Aspects to be considered in performance include technical skills, accuracy, musicianship, presentation, communication skills and ensemble awareness.

For the Irish and Scottish traditional music examinations offered by LCM, candidates are expected to perform the set tunes and supporting tests with fluency and continuity, a sense of style and musical character (including the adoption of phrasing, dynamics and musical character associated with a particular region and community) and practical and aural musicianship (the ability to manipulate music by ear, the visual communication between master and pupil or between musicians in a session). Assessment criteria include fluency of music, style and sense of style, confident sense of tonal and ornamental control, appropriate to the pieces performed and a well-rounded and engaging programme.

In addition to the performance of the musical instruments, other components of an examination include sight-reading, improvisation, ear tests and a viva voce. As indicated in the aforementioned section on traditional music examinations, some examinations include the theoretical section which asks candidates about the instruments, performers and the music. As stated in the manual, the Irish and Scottish traditional music exams are also designed to encourage the candidate to develop aural awareness of rhythm, melodic shape, echoing of phrases, extemporisation and harmonic accompaniment to a variety of tune idioms in a faceto-face situation with the examiner, secure intonation and a sense of performance.

It can be summarised that irrespective of the examination system, some assessment criteria are similar and these would include:

1. Musical elements (accuracy of pitch, rhythm, text, articulation, score accuracy, etc.);

2. Instrument technique (the ability to control the instrument with musical intent); and

3. Presentation (expressivity with regard to phasing, inflection and style, collaborate musically with others).

The review of related literature shows that established graded examinations are mostly for Western classical music. Only in the last 20 years has graded examinations been established for non-Western classical music genres. However, these examinations are limited to Chinese, Indian, Scottish and Irish music. Most of the existing graded examinations are also offered for solo instruments. In addition, for some of these examinations, assessment criteria are specific to the tradition and there is a viva voce component as well. Clearly, there is a need for graded examination systems for music from other musical traditions including that of Southeast Asia. As such, this study sought to develop a graded examination system for the Malay gamelan.

\section{Method}

This study is part of a project which aimed to investigate a structured approach for the assessment of musical attainment for musicians involved in Malaysian 
traditional music and to develop a graded examination syllabi for selected Malay traditional music.

The study was conducted in three phases. The initial phase of the study involved desk work where secondary data were gathered. Reference materials on the teaching and learning traditions of traditional music were gathered from libraries, National Archives, Ministry of Information, Communication and Culture, State Arts Department and the Malaysian Examination Syndicate. In addition, existing music examination systems for both Western and non-Western music traditions practiced in other countries were analysed.

Phase two of the research project involved fieldwork. The focus of the field work was on gathering data on how the gamelan is taught, learned and performed both in Malaysia and Indonesia. Observations of the teaching and learning practices as well as performances were documented in the form of field notes and audio visual recordings.

The third phrase and the main method of collecting data for this study was through a focus group with a panel comprising of five gamelan practitioners with more than 15 years' experience in teaching and performing the Malay gamelan. Their knowledge, experience and direct involvement as practitioners and/or academicians were vital for the purpose of the study and became the main criteria for selecting them as participants for the study. The focus group was conducted to identify the elements within the music examination system such as the syllabi, criteria for assessment, repertoire and contents. The data was then analysed and presented to the panel of experts again for verification.

\section{Findings}

Traditional music genres encompass a different theory, philosophy and practice from the western paradigm and differ markedly in the learning, teaching, knowing and understanding of the music. It is therefore imperative that these differences be taken into consideration when developing the graded exam for the gamelan as music differs from culture to culture with its own distinct meaning, values and musical function and the music is not generally theorised by performers but learned by playing the music (Dunbar-Hall, 2009).

\section{The Teaching and Learning Process}

The teaching and learning of the Malay gamelan differs from location to location and from teacher to teacher although the differences may not be markedly big. Nevertheless, it was a general consensus that the psychomotor, cognitive and affective domains were all equally important in the teaching and assessment of the gamelan. This is similar to the teaching of Western musical instruments, however, the attention given to each of the domains, for example, are seen in different ways particularly since the Malay gamelan is played as an ensemble.

All the gamelan practitioners interviewed agreed that the teaching of the gamelan inadvertently begins with an introduction to the cultural context and 
background knowledge of the genre before moving to the practical component. These include the origin and history, introducing students to the anatomy of the instruments and their role in the ensemble, performance practice, ethics during practice and in performance and the basic care and maintenance. As stated by the practitioners:

Semua harus tahu dari permulaan...materi dasar...budaya, peranan, fungsi, alat muzik, muzik.

[Everything needs to be known from the beginning...the basic materials...culture, role, function, music instruments, music.]

Sekarang ini pantang larang yang biasanya jangan langkah atas alat, hormat peralatan sebab kita nak cari rezeki dengan dia...kena hormat...tak elok langkah. Letak kaki atas gendang begitu juga alat lain jadi tak sopan.

[Nowadays the usual taboos is not to step over the music instruments, respect the musical instruments because we want to find sustenance through them ... respect ... it is not good to step over them. It is rude to place your foot on the gendang as well as other musical instruments.]

The learning process of the gamelan is typically via the master and apprentice mode whereby students learn by observing and imitating the master. Playing music is taught and learned through practical activity, relying on repetition as the main mode of learning. The skill of playing an instrument is learned as one learns the music. Unlike learning Western music instruments, method books are not used. As such, technical exercises in the Western sense is not used in the learning process.

One of the most important aspects in music making and music learning in the Western classical music tradition is reading music notation. Consequently, sightreading skills and playing using notation are important aspects assessed in international graded music examinations. Reading music notation is not an authentic practice as far as most Malaysian traditional music is concerned as the tradition is sound-based and non-notated, although some form of notation may be used if teaching in an educational setting.

As such, sight-reading skills and playing using notation are non-important aspects in the Malay traditional music_making and learning as it is in the teaching of Western music instruments. Traditionally, music learning is by memory and all practitioners expressed the importance of playing by memory so that players could play with the right 'soul and feel' and develop aural sensitivity. The following excerpt shows an example of a practitioner's views regarding the use of notation in music learning and making:

Muzik barat beza dengan muzik etnik di mana muzik barat ada notasi tetapi muzik etnik tidak ada. Kalau menggunakan notasi dalam gamelan, hanya sebagai kerangka, bukan untuk dimainkan.

[Western music is different from ethnic music as notation is used in Western music but not for ethnic music. With the gamelan, notation is used as a framework, not for playing.] 
Knowledge, understanding and skills required at each grade are made explicit through the repertoire selected to be taught and examined in graded exams (Robbins, 2007). The selection of repertoire needs to take the relative level of knowledge and skills a musician has to have reached for a particular grade into consideration. Factors such as the interaction of techniques, skills, knowledge, appropriateness of content, levels of expectation and what is to be taught needs to be taken into account.

Traditional music is not composed to accommodate the learner's abilities, i.e., for children and for adults. There does not appear to be a division between repertoire for children to learn and those for adults. In terms of levels of difficulty though, there was general consensus among the practitioners that the teaching of repertoire advances according to levels of difficulty. Although practitioners were in agreement that repertoire progresses from simple to difficult, some had varying opinions in what they felt constituted simple or difficult repertoire. Some practitioners looked at it in terms of the length of the repertoire, the form, complexity of the melody and/or rhythm, while others considered the complexity of the gendang parts or the improvisation. In addition, the nature of the art form and the semi-improvisatory style of traditional music would require the inclusion of this aspect as criteria of assessment. The possibility of having various interpretations of a repertoire performed including improvisation depending on the location and performance practice of the group is another point of consideration.

Bermula dengan yang mudah ke sukar dari segi panjangnya gendhing, tingkat kesukaran, tempo, pola irama. Bagi peringkat lanjutan, dimasukkan improvisasi. [Begin from simple to complex in terms of length of piece, level of difficulty, tempo, rhythm. For the advanced level, improvisation is added.]

Kita kena ajar ikut step dia lah sikit-sikit, dari senang ke susah, tapi... senang ke susah ka, macam mana pun semua kena belajar jugak, sebab dia lagu wajib. Ada lagu boleh potong [tak perlu dipelajari] tapi lagu wajib tu kena belajar.

[We need to teach gradually according to the steps, from easy to difficult, but... regardless of the difficulty, they all have to be learned because those are compulsory songs. There are songs that can be cut [do not have to be learned] but the compulsory songs have to be learned.]

Muzik barat beda dengan muzik etnik di mana muzik barat ada notasi tetapi muzik etnik tidak ada. Kalau menggunakan notasi dalam gamelan, hanya sebagai kerangka, bukan untuk dimainkan.

[Western music is different from ethnic music as notation is used in Western music but not for ethnic music. With the gamelan, notation is used as a framework, not for playing.]

Kalau ikut orang dulu-dulu, dia gunakan hafalan. Benda ni makan masa...yang lama...sebab nak hafalkan... hafal bunyi, hafal main...kalau ada yang bertulis ni pun dia bukan macam sistem notasi barat, dia sekadar tulis...cuma istilah orang kampung...tapi dia kena hafal jugak...Bila main kita dah pandai tahap mahir tak boleh pakai skor dah. 
[For the old schools, they used rote. This thing takes time... a long one... because the need to memorise... memorise the sound, memorise the playing... even the notations written are unlike the Western notation, they were simply written... but in villagers' term... yet they still need to memorise... When one reaches skilful playing, the score cannot be used anymore.]

Sebenarnya tradisional ni memanglah dia hafal kan, tapi kalau nak dikembangkan [idea muzikal] bila ada skor...tak la semua nak kena hafal.

[Of course the traditional music is to be memorised, but if the [musical ideas] are to be developed when there is a score... not everything is required to be memorised.-]

\section{Affective Component}

Music is expressed differently for everyone. As an oral tradition, music is generally in the mind of the musician and controls the musician. As such, expression is an important component in teaching traditional music. All the practitioners interviewed were in consensus on the importance of rasa (feel) and jiwa (soul) that is to feel the soul of the music. In their opinion, rasa and jiwa can only be achieved through good understanding of the music tradition as well as through appropriate techniques of playing in order to get the right touch. In addition, all the subjects interviewed stressed that playing by ear is crucial in achieving the rasa and jiwa.

Traditional music playing is a collaborative activity, relying on musical interdependency in close physical proximity. Being an oral tradition, there is somewhat limited verbal interaction involved in the learning process. Non-verbal forms of musical communication, such as eye signals and hand gestures, are used to facilitate the learning process. A community is created bonded by the musical necessity of listening to each other. As the gamelan is taught in a group situation, all group members are equally responsible for translating musical knowledge into musical sound. Gamelan playing is also communal in the sense that if one player is not available, another can take over. Therein lies another reason why gamelan players should know how to play all the instruments. Attitude, expression, cooperation, mutual understanding, unity, interaction of players and dexterity are key words used by the practitioners when discussing traditional music.

Afektif merupakan komponen yang penting dalam penilaian di setiap tahap...pola fikir, sikap, perilaku, etika, penjiwaan, pengolahan rasa... Silibus perlu merangkumi semua ini dalam konteks budaya.

[Affective is an important component in the appraisal of every level...pattern of thought, attitude, ethics, inspiration, feeling process... The syllabus needs to encompass all of these in cultural context.]

Teknik orang dan teknik kerjasama...wiraga (hafal struktur muzik), wirama (tempo dan dinamik), wirasa (perasaan, mud dan ekspresi).

[People technique and cooperation technique... wiraga (memorising the music's structure), wirama (tempo and dynamics), wirasa (feeling, mood and expression).] 
Konsep gamelan adalah berpegang kepada satu rasa, kesepakatan, kebersamaan kunci kepada gamelan.

[The concept of Gamelan is holding onto oneness, unity, togetherness is the key to gamelan.]

\section{The Malay Gamelan as an Ensemble}

A recurring issue that was raised by all practitioners was the consideration of the type of ensemble and the context of teaching traditional music and hence, the assessment of traditional music. In the case of the gamelan, all practitioners interviewed are of the opinion that students have to learn all instruments within the ensemble.

Looking at the gamelan, it can be seen that there are many differences in characteristics when it comes to the gamelan ensemble as opposed to Western ensembles. The practitioners interviewed agree with Supanggah (2008) on the differences including the emphasis on togetherness with no individual instrument dominating, the importance of the high level of sensitivity and depth of feeling as opposed to personal virtuosity and the importance of aural sensitivity in playing the gamelan where musical dialogue occurs through listening.

Given that the gamelan is an ensemble tradition, teaching occurs in a group and is highly repetitive. The practitioners interviewed generally agreed that it is important for gamelan musicians to learn all the instruments within the ensemble as a part of their training. Individual skills, the ability to cooperate within the ensemble and creativity within the context of the ensemble are also aspects assessed.

The nature of the gamelan as an ensemble will demand different approaches to assessment. The assessment of the gamelan will require the student to rotate until a sampling of instruments from the various groups or all instruments have been assessed. As evidenced through observations and field notes during the data collection process, one aspect to be considered in determining the framework of an examination board for Malaysian traditional music genres is establishing a mechanism to assess the different instruments within the ensemble. Differentiating and equating the contributions of the different instruments within the ensemble will therefore also need to be accounted for.

\section{Discussion}

As indicated by McPherson and Thompson (1998), the selection of evaluative criteria and evaluative instruments strongly shape the evaluation process. Following the curriculum design, the assessment criteria for the gamelan need to be determined and as with any music instrument, must include among other aspects, the technical and musical competence, interpretative understanding and stylistic awareness. In traditional music, playing from memory, playing by ear and improvising are additional aspects that need to be considered. As the gamelan will be assessed in an ensemble setting, the criterion has to be ascertained for the performance of each instrument within an ensemble and as an ensemble. For ensembles such as the 
gamelan where musicians are expected to play all the instruments, the allocation of marks has to consider the nature and function of the instrument.

In terms of repertoire, the number of pieces to be assessed and the criteria for selecting repertoire, such as being easy to listen to, likeable, popular or standard pieces, need to be determined. In addition, if an instrument is used in different types of ensembles, consideration has to be given if assessment should be based on repertoire from a selected form of traditional music genre or repertoire from the various genres in which the instrument is used. Performance on different musical instruments may also be assessed differently because they involve different technical skills and are associated with different repertoire.

Traditional music is, by nature, an oral tradition in which learning is by nonformal education, i.e., by listening, observing and playing. Aural sensitivity is very important where musical dialogue occurs through listening. In these genres examined, musical changes are marked or led by the gendang through aural signals. Emphasis is placed on cooperation and togetherness in the ensemble with no individual instrument dominating and in which a high level of sensitivity and depth of feeling are important as opposed to personal virtuosity (Supanggah, 2008). This leads to the implication that the affective component or jiwa (expression) is an important criteria of assessment.

As an oral tradition, music is expressed differently for everyone. As such, expression is an important component in teaching traditional music. The possibility of having various interpretations of a repertoire performed, including improvisation and depending on the location and performance practice of the group has to be considered during assessment. The three domains of learning, i.e., the cognitive, psychomotor and affective, have to be cumulatively assessed. As stressed by the practitioners, there has to be a balance between performance skills, knowledge, thought patterns, attitude, conduct/behaviour and ethics that collectively make up the culture of the music tradition.

\section{Graded examination for the Malay gamelan}

Taking into consideration the data from the interview with practitioners, documentary research and the conclusions of the research, the following recommendations for the development of a graded examination for the gamelan is set out below:

1. The examination will assess the three domains of learning, i.e., cognitive, psychomotor and affective.

2. The syllabus will be divided into three levels: beginner (Level 1), intermediate (Level 2) and advanced (Level 3). Each level is further subdivided with beginner's level having 3 grades (Grades 1-3), three grades in the intermediate level (Grades 4-6) and two grades in the advanced level (Grades 7-8).

3. Candidates will be examined on all instruments. Level 1 begins with the saron and colotomic instruments. As the level progresses, the improvisatory 
instruments (bonang and gambang) and the gendang are included. Improvisation, however, will only be introduced in Level 3.

4. Techniques specific to the Malay gamelan will be assessed such as damping, cincang, bunga (improvisation) and turun gambang.

5. Repertoire will progress according to the level of difficulty, both melodically and rhythmically, according to the length of the lagu.

6. Repertoire will be performed from memory.

7. The practical and theoretical aspects of a performance for assessing Malay traditional music will be included .

a) The practical aspect relates to aspects assessed during the performance part of the exam and is further subdivided into two components which are musical and non-musical factors. The musical factor includes the technical dimension, musical dimension and presentation. The technical dimension refers to technical competence on an instrument in terms of tone production, intonation, the ability to perform a range of techniques with control and fluency and the accuracy of musical elements, which involves the accuracy of pitch, rhythm, tempo, articulation and text articulation. The musical dimension refers to the understanding of musical, stylistic and expressive issues. This involves musical awareness and interpretative understanding of the music performed including aspects such as phrasing, dynamics and ensemble awareness. Ensemble awareness refers to individual contribution to the cohesive sound of the group including awareness of intonation, blend and balance, tempo and style and unity of feeling. The affective component or jiwa is an important aspect to be assessed. In these genres examined, musical changes are marked or led by the gendang through aural signals. The non-musical factor of the performance section refers to elements such as attitude of the musicians when functioning in an ensemble, cooperation, rapport with the music and the instruments and mutual understanding among the musicians.

b) The theoretical aspect includes a viva voce component, which concerns the knowledge of the music being assessed in terms of the history, background, instruments, repertoire and performance practice. Questions will be set according to the respective grade level and include questions on the comprehension of music elements, terms, techniques, instrumental functions, repertoire, musical style and an understanding of the aesthetics of the gamelan.

8. In contrast to examinations in Western musical instruments, sight-reading will not be examined. 


\section{Conclusion}

The establishment of an assessment and certification system based on international graded music examination systems for local traditional music is crucial for the future survival and sustainability of Malay musical heritage. If the aforementioned suggestions are taken into consideration when designing the graded examination syllabus, the music and performance practice of this genre will be sustained. However, the effort towards the establishment of a system and standard is evidently quite challenging. Issues like authenticity and cultural imperialism need to be taken into considerations and addressed appropriately in order to ensure acceptance and success of the assessment and certification system to be developed.

\section{References}

ABRSM Annual Review 2005 (2005). Retrieved from http://www.abrsm.org/resources/abrsmAnnualReview05.pdf

Choo, M. Y. (2003). Kesedaran dan kepentingan mewujudkan badan peperiksaan muzik tempatan di Malaysia. (Unpublished master's thesis). Universiti Malaysia Sarawak, Kuching.

Dunbar-Hall, P. (2009). Ethnopedagogy: Culturally contextualised learning and teaching as an agent of change. Action, Criticism, and Theory for Music Education 8 (2), 60 78.

Leung, C.C. (2003). The role of Chinese music in secondary school education in Hong Kong. (Unpublished doctoral dissertation). RMIT University, Melbourne, Australia.

McPherson, G. E., \& Thompson, W. F. (1998). Assessing music performance: Issues and influences. Research Studies in Music Education, 10, 12-24.

Mohd. Fadzil Abdul Rahman \& Thia, S. S. (2005). Establishing the Malaysian music examination board: Isn't it timely? Paper presented at the $3^{\text {rd }}$ Malaysian Music Education Conference, Perak.

Mohamed Ghouse Nasuruddin. (1979). Dance and music of the performing arts of Malaysia. (Unpublished doctoral dissertation). Indiana University, Indiana, United States.

Nettl, B. (1985). The western impact on world music: Change, adaptation, and survival. New York, NY: Schirmer Books.

Razak Baginda. (2002). Malaysia in transition: Politics and society. Kuala Lumpur: Asean Academic Press.

Robbins, J. H. (2007). Whose performance is it anyway? Reflections on examining music, meanings, standards, and reliability in an international context. Paper presented at the $33^{\text {rd }}$ Annual IAEA Conference, Baku.

Ross, V. (2002). External public piano examinations in Malaysia: Social and symbolic significance. (Unpublished doctoral dissertation). Deakin University, Victoria, Australia.

Shahanum Mohd Shah. (2000). Relationships among musical style, ethnicity, age, gender, musical training, familiarity, intercultural tolerance and music preferences of Malaysian students. (Unpublished doctoral dissertation). Indiana University, Bloomington.

Shahanum Mohd Shah \& Zaharul Lailiddin Saidon. (2016). Sustainability of Malay traditional music via a graded music examination system: The Malay gamelan. In 
Santoso S. Kar. \& Donie Fadjar Kurniawan. (Eds.) Proceedings Paradigms in Art Creations and Art Studies. The $1^{\text {st }}$ International and Interdisciplinary Conference on Arts Creation and Studies, (pp. 56-69). Surakarta: ISI Press.

Supanggah, R. (2008). Pengalaman mengurus, memperlengkap dan memperluas kaedah pengajaran seni di Sekolah Tinggi Kesenian Indonesian (pengkhususan seni muzik dan tari gamelan). Paper presented at the World Gamelan Symposium and Festival 2008, Terengganu, Malaysia.

Wan, A. Kadir (2008). Muzik sebagai warisan perubahan dan identiti seni muzik kebangsaan. Paper presented at the Seminar Seni Muzik Kebangsaan 2008, Akademi Seni Warisan dan Kebudayaan, Kuala Lumpur.

Yeoh, M. P. (1999) Music preferences of undergraduate students in a multi-musical country. (Unpublished master's thesis). Universiti Putra Malaysia, Serdang, Selangor.

Zaharul Lailiddin Saidon \& Shahanum Mohd Shah (2015). Penilaian dan pensijilan bagi muzik tradisional Malaysia berdasarkan model peperiksaan bergred antarabangsa. Malaysian Music Journal, 4 (1), 47-66.

\section{Biography}

Shahanum Mohamad Shah is an associate professor of Music Education at Universiti Teknologi MARA, Malaysia. She holds a Bachelor of Music (Performance) (Hons.) degree from Adelaide University, Australia, and a Master and $\mathrm{PhD}$ degrees from Indiana University, Bloomington, United States of America. Her primary research interests include psychology of music, teaching and learning or music, assessment and the Malay gamelan.

Zaharul Lailiddin Saidon is an associate professor of Music Education at Sultan Idris Education University (UPSI), Tanjong Malim, Malaysia, where he teaches courses in music education and marching band techniques. Zaharul currently serves as the Dean of the Faculty of Music and Performing Arts at the university. He received his undergraduate degree in music from Southern Illinois University, United States of America (USA), and his master's degree in education from the University of Houston, Texas, USA. Zaharul is one of the founding members of the Malaysia Band Association and the Malaysian Association for Music Education. 